\title{
SWOT ANALYSIS IN AN EDUCATIONAL INSTITUTION (Case Study: Baitul Qur'an Islamic Boarding School, Depok)
}

\author{
Gina Rohadatul Aisyi ${ }^{1}$, Lutfi Zulkarnain ${ }^{2}$
}

${ }^{I}$ SEBI: Email: Ginaisyi@gmail.com

${ }^{2}$ SEBI Lecturer Email : Lutfizulkarnain@gmail.com

\begin{abstract}
The development of the educational institution industry continues to increase, which demands an effective marketing strategy to face the increasingly tight competition in the education service business. This research is a qualitative research methodology with a descriptive approach that aims to determine the marketing strategy of Baitul Qur'an educational institutions. The analysis tool used is the analysis of the company's environment (EFE, IFE, and IE Matrix) with the SWOT method (Strength, Weakness, Opportunity, Threat). The results of the Baitul Qur'an Islamic Boarding School evaluation based on Internal and External analysis obtained from the SWOT analysis resulted in an alternative strategy of S-O (Strength-Opportunity). Then, the results of the SWOT analysis are reprocessed using the QSPM (quantitative strategic planning matrix) method to obtain priority strategies from various alternative strategies as well as a decision to choose a strategy. The priority strategy in this study is to optimize the use of digital marketing and other marketing technologies to support the development of Islamic boarding schools in a wider area $(6,87)$.
\end{abstract}

Keywords: Marketing Strategy, Educational Institution, SWOT, QSPM

\section{INTRODUCTION}

The birth of educational institutions such as pesantren, madrasas, majlis taklim, and Islamic religious colleges is inseparable from the stages and conditions of the era, but what is clear is that educational institutions can be traced to their origins or genealogy. When the Dutch colonized Indonesia there were three types of Islamic educational institutions namely (1). The place for the Koran recitation which provides basic religious education (2). Islamic boarding schools that provide structured religious education (3). The Ulamaled tarekat, which provides training in the punishment of Islamic doctrine.

Islamic education is any effort or educational process carried out to guide human behavior both individually and socially, to direct the potential of both the basic potential of nature and teaching in accordance with their fitrah through intellectual and spiritual processes based on Islamic values to achieve happiness in living in the world and the hereafter (Dr. HM Suyudi, 2005, p. $55)$.

Islamic education institutions in Indonesia developed long before the Islamic-based educational institutions established by Muhammadiyah were 
born and developed when Muhammadiyah Islamic education was more formal and official with modern educational patterns.

Whereas in Law no. 20 of 2003 article 13 paragraph 1 concerning the division of education which includes three areas: formal, non-formal, and informal education. Formal education is an educational institution that is structured and tiered which is officially managed by both the government and the private sector, such as elementary, junior high school, high school and tertiary education. Included in Islamic (religious) education can be similar to diniyah ibtidaiyah (MI), tsanawiyah, aliyah, and the like.

According to the Statistical Summary Data for Primary and Secondary Education through the Ministry of Education and Culture, the number of schools in Indonesia in the 2016/2017 academic year is as follows:

Table 1.1 Number of Schools by Education Level and School Status in Indonesia 2016/2017

\begin{tabular}{|c|c|c|c|c|c|c|c|}
\hline \multirow[t]{3}{*}{ No } & \multirow{3}{*}{$\begin{array}{ll}\text { Level of } \\
\text { Education }\end{array}$} & \multicolumn{6}{|c|}{ School Status } \\
\hline & & \multicolumn{2}{|c|}{ Public } & \multicolumn{2}{|c|}{ Private } & \multicolumn{2}{|c|}{ Total } \\
\hline & & No. & $\%$ & No. & $\%$ & Total & $\%$ \\
\hline 1 & $\begin{array}{l}\text { Elementary } \\
\text { School (SD) }\end{array}$ & $\begin{array}{c}132.0 \\
22\end{array}$ & $80 \%$ & $\begin{array}{c}15.48 \\
1\end{array}$ & $32 \%$ & $\begin{array}{c}147.5 \\
03\end{array}$ & $69 \%$ \\
\hline 2 & $\begin{array}{l}\text { Junior High } \\
\text { School (SMP) }\end{array}$ & $\begin{array}{c}22.80 \\
3\end{array}$ & $14 \%$ & $\begin{array}{c}14.96 \\
0\end{array}$ & $31 \%$ & $\begin{array}{c}37.76 \\
3\end{array}$ & $18 \%$ \\
\hline 3 & $\begin{array}{l}\text { Senior High } \\
\text { School (SMA) }\end{array}$ & 6.567 & $4 \%$ & 6.577 & $14 \%$ & $\begin{array}{c}13.14 \\
4\end{array}$ & $6 \%$ \\
\hline 4 & $\begin{array}{l}\text { Vocational } \\
\text { School (SMK) }\end{array}$ & 3.434 & $2 \%$ & 9.802 & $20 \%$ & $\begin{array}{c}13.23 \\
6\end{array}$ & $6 \%$ \\
\hline 5 & $\begin{array}{l}\text { Special School } \\
\text { (SLB) }\end{array}$ & 545 & $0.3 \%$ & 1.525 & $3 \%$ & 2.070 & $1 \%$ \\
\hline \multicolumn{2}{|c|}{ Total } & $\begin{array}{c}165.3 \\
71\end{array}$ & $100 \%$ & $\begin{array}{c}48.34 \\
5\end{array}$ & $100 \%$ & $\begin{array}{c}213.7 \\
16\end{array}$ & $100 \%$ \\
\hline
\end{tabular}

Source: Data Summary of Primary and Secondary Education Statistics through the Indonesian Ministry of Education and Culture, 2016

The reality of education that appears now shows that community participation in providing non-formal education services continues to increase. Various non-formal education units that are developing and increasingly mushrooming are the Boarding Schools.

According to the Islamic Education Analysis Data, the largest number of Islamic boarding schools in Indonesia in 2011/2012 is as follows: 
87 | Gina Rohadatul Aisyi, Lutfi Zulkarnain : SW0T Analysis in an Education Institution (Baitul Qur'an Islamic Boarding School, Depok)

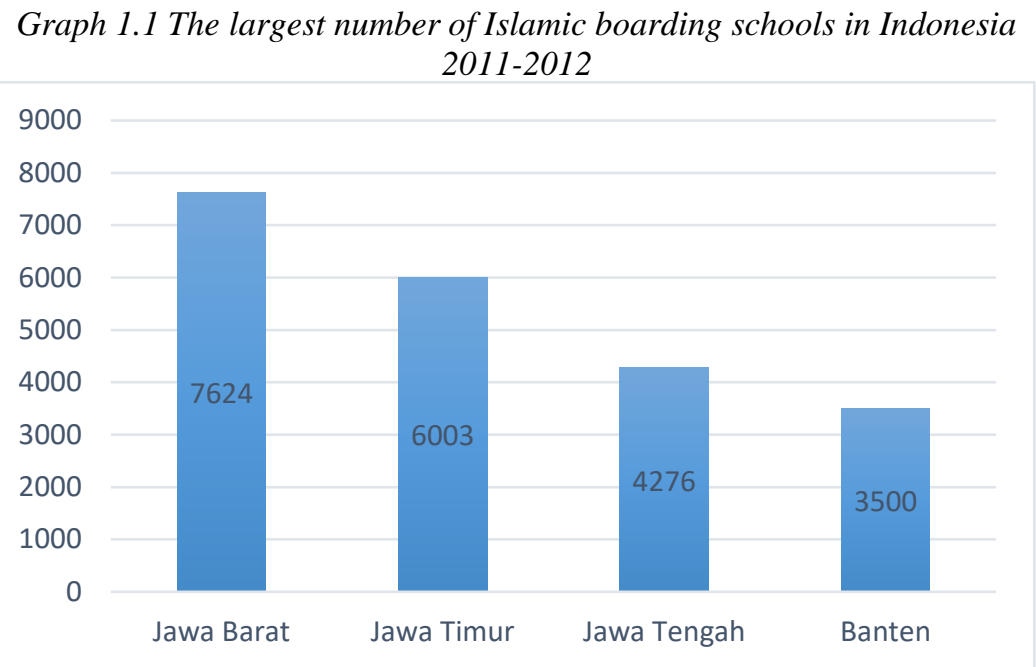

Source: Islamic Education Analysis Data, 2011

From the data above, we can see that West Java dominates the presence of Islamic boarding schools in Indonesia, with details of West Java $28.00 \%$, East Java $22.05 \%$, Central Java $15.70 \%$, and Banten $12.85 \%$ of the total $78.60 \%$ of the total number of Islamic boarding schools in Indonesia.

The purpose of establishing Islamic boarding schools is to create a Muslim personality that is a personality that has faith and devoted to God, noble character is beneficial to society, free and firm in personality, spreading and upholding the religion of Islam (Dr. Mastuhu, 1994). Meanwhile, the character of formal education which is very black and white focuses more on national exams, link and match, bureaucracy, diploma achievement, and democracy can actually be considered to be disrupting the continuity of achievement of the main goals of the Tahfidz Islamic Boarding School.

Especially for the existence of Islamic Boarding School that is as an educational institution that has played an active role in building the nation through religious education, community development and institutions that are able to become a stronghold of morality and national morals from foreign cultures that are not good. In the course of time to time, the Islamic Boarding Schools not only act as educational institutions, but their roles have expanded to become the basis for encouraging social and national transportation to all levels of society. From this very heavy role, it is necessary to improve the quality of education from various sides, both from the physical side (facilities and infrastructure), as well as from various non-physical aspects (human resource development, administration, management and others).

At this time, the study of the Tahfidz Al-Qur'an is considered very significant to be developed. Many Islamic educational institutions in Indonesia today promote and develop the Tahfidz Al-Qur'an program. This shows the high enthusiasm of the Indonesian Muslim community to memorize the Al- 
Qur'an and make their children memorize the Al-Qur'an. This trend is also a sign of the progress of Islamic education. Although actually memorizing the Al-Qur'an is not something new for Muslims, memorizing the Al-Qur'an has been around for a long time in Islamic boarding schools.

Learning Tahfidzul Qur'an continues to bloom until modern times now. In fact, almost all major cities in Indonesia have many Tahfidzul Qur'an schools. Also the interest of the whole Muslim community in Indonesia in the Al-Qur'an continues to increase. This indication can be seen from the increasing number of institutions and communities that love Al-Qur'an as well as the more creative and attractive methods for teaching the Qur'an in this country.

One example of a Tahfidz educational institution is the Baitul Qur'an Islamic Boarding School or also called the Baitul Qur'an Indonesia Foundation. This Islamic boarding school is an institution that is engaged in social education and da'wah, this institution tries to cadre the Koran memorizers who also understand it at the same time. Which presents programs such as Tahfidz Al-Qur'an 30 juz, free Islamic boarding schools, free school programs (SMP and SMA), the preachers memorizing the Qur'an program, and STIQ Baitul Qur'an (Qur'anic College ). Located in the Depok area, it was founded in 2006.

For the scope of schooling, the Baitul Qur'an Islamic Boarding School is well known in the city of Depok as a Tahfidz institution for orphans and dhuafa from junior high school, high school as well as STIQ which are trying to train their students to memorize the Al-Qur'an and understand it. The programs offered by the Baitul Qur'an Islamic Boarding School are very interesting, have good learning methods and objectives to develop a child's character to memorize the Al-Qur'an.

\section{LITERATURE REVIEW}

\section{Understanding Educational Services}

Kotler in the book Integrated Services Management defines services as any action or activity that can be offered to other parties, basically intangible and does not result in any ownership, the production of services may be related to physical products or vice versa (Nasution, 2004, p. 6).

Services are basically all economic activities with output other than products and physical terms, consumed and produced at the same time, providing added value and in principle being intangible (intangible) to the first buyer.

Services are covering all economic activities that produce nonphysical products or construction, which are normally consumed at the time of production and add value to forms such as practicality, suitability, comfort, and health, which in essence, attracting taste to the first buyer. Meanwhile, education services are complex services due to their labor and capital intensive nature. This means that it takes a lot of workers who have special skills in the field of education and are capital intensive because they require complete infrastructure (equipment) and are expensive. 
89 | Gina Rohadatul Aisyi, Lutfi Zulkarnain : SW0T Analysis in an Education Institution (Baitul Qur'an Islamic Boarding School, Depok)

Education is a process of humanizing humans or a process that must be carried out both institutionalized and non-institutional, which involves physical and non-physical matters and requires infrastructure and skills or skills. Thus educational services are all activities related to education that prioritize service in the process.

\section{Educational Service Products}

Products are anything that can be offered to the market for attention, possession, use or consumption so as to satisfy wants or needs. In educational services, the products offered to students are reputation, prospects, and variety of choices. A good school offers a high reputation / quality of education, prospects for students after graduation, and a choice of concentration in various programs so that prospective students can choose a field that suits their talents and interests (Minarti, 2012, p. 390).

Products in general are anything that a producer can offer to be noticed, requested, purchased, used, or consumed by the market as a fulfillment of the needs or desires of the relevant market. The products offered include physical goods, services, organizations, and ideas. Products from schools are educational services that can be detailed on:

- Curricular services include curriculum, general syllabus (GBPP), design of learning materials, presentation of learning materials, and evaluation.

- Research services, in the form of various studies and their results or the development of teachers' abilities in researching and reading research results.

- Extracurricular services include various service activities outside of curricular services, such as arts activities, sports, crafts and others.

- Community life development services include services to develop the ability of students to live in a community such as observing the life of farmers, entrepreneurs / industrial companies, visiting hospitals, visiting houses of worship, orphanages and providing assistance and others.

- Administrative / administrative services, in the form of services for various certificates, cover letters for students, reports on learning outcomes.

- Special services, in the form of guidance and counseling services, library services, school health business services, canteen services, and transportation or bus services.

- Educational service products can only be consumed by consumers during the production process. Meanwhile, other goods and services, apart from education, which can be seen physically are usually produced in factories or in certain places, then distributed by distributors to shops and only consumed by consumers. In the field of education services, the factor of education service providers (people) directly plays a role in the production process of these services. 


\section{Definition of Islamic Boarding Schools}

Pondok Pesantren, an Islamic educational institution, is the identity of the pesantren at the beginning of its development. Now that there have been many changes in society, as a result of its influence, the above definition is no longer adequate, although in essence the pesantren will continue to remain in its original function, which is always maintained in the midst of rapid changes. In fact, being aware of the flow of change that is often uncontrolled, outsiders see its uniqueness as a social area that contains the strength of resistance to the impact of modernization (Dhofier, 1994, p. 18).

Pondok Pesantren is an Islamic education with a boarding system where Ustadz is the central figure and the mosque is the center of the activities that animate it and Islamic teaching under the guidance of Ustadz is followed by santri as the main activity (Wiryosukarto, 1996, hal. 5).

\section{Definition of Sharia Strategy Management}

Sharia strategic management is a series of Islamic management activity processes that include the stages of formulation, implementation and evaluation of strategies to achieve organizational goals, where Islamic values form the basis of strategy in all organizational activities, which are colored by the principle of tauhid, worldly-ukhrawic orientation and mardhatillah motivation. (Usman, 2015, p. 63).

\section{Sharia Strategy Management Theories}

a. The principle of monotheism in the company

Determination of the principle of monotheism as the basis of all organizational / company activities, with absolute confidence that Allah SWT as ruler and self-regulator in totality only to Him, will add confidence for management and crew to successfully achieve the mission and goals of a better company and benefit the hereafter world .

b. Earthly-Ukhrawi Orientation

By setting the goal of worldly-ukhrawi oriented companies, namely obtaining worldly profits as well as benefits / benefits, will provide calm, tranquility and satisfaction in work and activities so that happiness can be obtained / felt in running the organization / company.

c. Motivation Mardhatillah

With the motivation of mardhatillah, that is, all organizational / company activities are intended solely because of Allah and hope for the reward and pleasure of Allah SWT, will provide a stronger impetus for the management and crew to achieve the success of their business in the world to the hereafter. Rasulullah SAW said: Meaning: "The validity of charity depends on the intention. Everyone will get something according to his intention ". (H.R Bukhari). 
91 |Gina Rohadatul Aisyi, Lutfi Zulkarnain : SW0T Analysis in an Education Institution (Baitul Qur'an Islamic Boarding School, Depok)

d. Ubudiyah's Belief in Work

With Ubudiyah's belief, namely believing that work is worship where all activities in the organization / company are solely intended as worship to Allah, will give strength to management and crew to face and overcome various obstacles and obstacles and provide calm, satisfaction, and happiness in work and do activities for the sake of expecting the pleasure of Allah SWT.

e. Ihsaniyah Awareness at Work

With the awareness of ihsaniyah, namely believing that all organizational / company activities are righteous deeds that are always known and under the supervision of Allah SWT, it will encourage management and crew to work as well as possible, honestly, trustworthy and Itqan (precise, perfect, complete) without having to be supervised by superiors, thereby encouraging the achievement of the best performance results. Rasulullah SAW said:

- Meaning: "Allah really loves people who if they do a job, it is done itqan (right, perfect, complete). (H.R. Thabrani).

\section{Definition of Sharia Marketing}

Sharia marketing or so-called spiritual marketing is marketing that is able to provide happiness to everyone involved in doing business, both ourselves, customers, suppliers, distributors, capital owners, and even competitors (Kertajaya \& Syakir, 2006, p. 16) .

Sharia marketing is marketing that is guided by the values of the faith, namely honesty, trustworthiness (credibility and responsibility), fathanah (smart and wise), tabligh (communicative), and so on (called soul marketing) which have been exemplified by the apostles of fifteen centuries. ago. (Hasan, 2010, p. 9)

Therefore, Islamic marketing is marketing based on spiritual values which involves not only managers and their stakeholders but also the values of the Shari'a determined by Allah SWT through the Prophet Muhammad.

\section{RESEARCH METHODOLOGY}

This study uses a qualitative research methodology with a descriptive approach. The types of data used in this study are primary data and secondary data. The source of data from the type of primary data for research is the result of direct interviews with related parties who handle the section concerned with the problem to be investigated by researchers. Secondary data is obtained from literature studies such as journals, books and theses. As a complement, researchers obtained data from the Central Statistics Agency (BPS), Digital Statistical Data, Depok City Education Office, and data from Baitul Qur'an Islamic Boarding School. 
The data collection technique in this study was to conduct direct interviews with the management of the Islamic boarding school in order to obtain valid information. Observations made by researchers were directly at the research location, namely the Baitul Qur'an Depok Islamic Boarding School and carrying out documentation.

\section{RESULTS AND DISCUSSION}

Starting from a Da'i Hafizh Al Qur`an Awareness Program which was fostered by K.H DR Muslih Abdul Karim, MA. In 2004, and in 2005, the Orphan and Dhu'afa Development Program was added. The idea arose to establish an institution that covered these programs, which was then born the Baitul Qur`an Indonesia Foundation which was formalized based on Notarial Deed on February 5, 2008. While the goal of establishing YBQI was aimed at helping the Ummah by providing facilities: Educational Institutions, Da 'Institutions wow, and Social Institutions.

The main value of the Baitul Qur'an Islamic Boarding School is an achievement in memorizing the Al-Qur'an and understanding it. Aiming to achieve this. The vision of fostering students to become the Qur'ani generation and the mission of providing nurture, education, and guidance to students so that they grow into the Qur'anic generation.

\section{Internal Environmental Analysis}

\section{a. History}

In carrying out its activities, the tahfidz al-quran program compiled its own curriculum by adopting several other pesantren curricula which also established the Tahfidz Al-quran program. Because until now there has been no official guideline issued by the boarding school itself or from the ministry of religion. In the midst of busy Islamic boarding school activities, it is not an obstacle for students to take part in the Tahfidz Al-quran program even though the implementation of the Tahfidz Al-quran activities is carried out between the students' break time, which is every day after Fajr and Asr prayers.

\section{b. Human Resources}

Human Resources (HR) is the most valuable asset in an educational institution. Thus, the management and development of human resources is important in its development.

Baitul Qur'an Islamic Boarding School has 8 core employees consisting of: 1 coach of the Baitul Qur'an foundation, 1 Director of Finance and Fundraising, 1 Manager of Finance, 1 Manager of Fundraising and Business, 1 Manager of Infrastructure, 1 Chair of the Islamic Boarding School, 1 Head of Curriculum Division, 1 Head of Tahfidz Division. Also HR as a teaching teacher for general subjects and Tahfidz.

\section{c. Financial aspect}

Finance is a fundamental component for the sustainability of a company. If the finances in a company can be managed properly, of course it 
93 | Gina Rohadatul Aisyi, Lutfi Zulkarnain : SW0T Analysis in an Education Institution (Baitul Qur'an Islamic Boarding School, Depok)

can give good results too. The purpose of a good financial arrangement is to maximize the income obtained and can be used properly.

The financial system used by Baitul Qur'an Islamic Boarding School uses a manual system. Financial input and management, both income and expenditure as a whole, is directly handled by the Pondok Pesantren. As for the main income is from the donors where the income is processed into various parts. Most of it is for operations, needs, facilities, and teachers' salaries.

Baitul Qur'an Islamic Boarding School itself does not use financial accounting standards, such as the Statement of Financial Accounting Standards-International Financial Report Standards (PSAK-IFRS), Financial Accounting Standards for Entities without Public Accounting (SAK-ETAP), PSAK-Sharia and also Accounting Standards. Government (SAP).

\section{d. Marketing Aspects}

In setting prices, the Baitul Qur'an Islamic Boarding School must pay attention to prices and adjust them according to circumstances, and not set higher prices, let alone lower prices, which can damage the selling price. Here are some details on the prices of several Baitul Qur'an Islamic boarding schools:

\begin{tabular}{|l|l|l|l|}
\hline No & Programs & Price & \multicolumn{1}{|c|}{ Information } \\
\hline 1. & $\begin{array}{l}\text { Free Boarding } \\
\text { Schools }\end{array}$ & Rp. 0,- & $\begin{array}{l}\text { Untuk Program } \\
\text { Pesantren Gratis }\end{array}$ \\
\hline 2. & $\begin{array}{l}\text { Tahfidz Al Qur'an } \\
\text { 30 Juz }\end{array}$ & Rp. 0,- & Tahfidz Al Qur'an 30 juz \\
\hline 3. & $\begin{array}{l}\text { Free School } \\
\text { Program (SMP dan } \\
\text { SMA) }\end{array}$ & Rp. 0,- & $\begin{array}{l}\text { Free School (SMP and } \\
\text { SMA) Program }\end{array}$ \\
\hline 4. & $\begin{array}{l}\text { Da'i Hafal Al- } \\
\text { Qur'an Program }\end{array}$ & Rp. 0,- & $\begin{array}{l}\text { da'i hafal Al Qur'an } \\
\text { Program }\end{array}$ \\
\hline 5. & $\begin{array}{l}\text { STIQ Baitul Qur'an } \\
\text { Rp. 0,- }\end{array}$ & $\begin{array}{l}\text { STIQ Baitul Qur'an is a } \\
\text { free program created by } \\
\text { the Baitul Qur'an Islamic } \\
\text { Boarding School to make } \\
\text { it easier for those who are } \\
\text { interested in memorizing } \\
\text { the Qur'an. }\end{array}$ \\
\hline 6. & TPQ Baitul Qur'an & $\begin{array}{l}\text { Rp. } \\
2.500 .000\end{array}$ & $\begin{array}{l}\text { The Al-Qur'an Education } \\
\text { Park is a program held to } \\
\text { accommodate the wider } \\
\text { community so that they } \\
\text { can learn the Al-Qur'an } \\
\text { together. }\end{array}$ \\
\hline 7. & $\begin{array}{l}\text { BILAL Baitul } \\
\text { Qur'an }\end{array}$ & $\begin{array}{l}\text { Rpternal guidance for the } \\
\text { community. }\end{array}$ \\
\hline
\end{tabular}


The location of the Baitul Qur'an Islamic Boarding School itself is located in the Timah Complex, Block CC III, No.19, Kelapa Dua, Tugu, Cimanggis, Depok, West Java.

The promotion carried out by the Baitul Qur'an Islamic Boarding School in marketing and educating its products is $60 \%$ through online media, such as using Facebook, Instagram, and Youtube accounts. Meanwhile, the other $40 \%$ go through offline media. Offline media is done by distributing brochures, then words of mouth and the environment, and finally by involvement to the community where he lives.

\section{External Environmental Analysis}

a. Technological Aspects

The existence of technological changes can encourage opportunities and improve efforts to achieve organizational goals. Technology can also be referred to as the productivity of a boarding school. But it can also be a threat to the existing sustainability. Several technology products that have been used as breakers that are able to create opportunities as well as threats to activities in Baitul Qur'an Islamic Boarding School include: computers with the use of internet services to mobile services, academic information systems, data collection, as well as the utilization of solar power. . Therefore, technological changes certainly affect the life cycle of a product. The product life cycle assessment and assessment can in turn determine the right timing for launching new products or modifying existing products.

\section{b. Competency Aspects}

Especially with the entry of Islamic boarding schools in Indonesia which have been around for quite a long time, the challenge itself is in facing competition from other Islamic boarding schools that have developed first, more experience and learning before the existence of the Baitul Qur'an Islamic Boarding School. This competition includes various forms: competition among similar Islamic boarding schools, the threat of new competitors, and competition for the development of substitute products.

\section{SWOT analysis}

Strength (Strength)

a) Islamic boarding schools have an extensive network of collaboration

b) Has a network of contact persons from alumni who are scattered outside the island of Java

c) Work environment and program environment that apply the values of the Qur'an

d) Legality of Islamic boarding schools that already have legal entities Weaknesses (Weeknesses)

a) Human resources for marketing personnel that must be improved

b) Work management is still not good

c) There is a double job for the Asatidz 
95 | Gina Rohadatul Aisyi, Lutfi Zulkarnain : SW0T Analysis in an Education Institution (Baitul Qur'an Islamic Boarding School, Depok)

d) Lack of land to expand the location of Islamic boarding schools in one location

e) Lack of teaching facilities in Islamic boarding schools

\section{Opportunities (Opportunities)}

a) The growing marketing technology provides opportunities for wider market development

b) Good relationship with donors

c) Many Islamic boarding schools are the same in the Tahfidz program so that they can work together well

d) Support from local governments and other agencies

\section{Threat}

a) The emergence of new competitors establishing similar Islamic boarding schools which are superior in several ways

b) Lack of interest from donors because the programs implemented did not go according to plan

\section{External Factor Evaluation Matrix (EFE)}

\begin{tabular}{|l|c|c|c|}
\hline \multicolumn{1}{|c|}{ External Strategy Factors } & $\begin{array}{c}\text { Weig } \\
\text { ht }\end{array}$ & Rating & Score \\
\hline $\begin{array}{l}\text { Opportunity } \\
\text { 1. Marketing technology is increasingly } \\
\text { developing, providing opportunities for } \\
\text { wider market development }\end{array}$ & 0,20 & 4 & 0,8 \\
$\begin{array}{l}\text { 2. Good relationship with donors } \\
\text { 3. Many Islamic boarding schools are the } \\
\text { same in the Tahfidz program so that they } \\
\text { can work together well }\end{array}$ & 0,15 & 3 & 0,45 \\
$\begin{array}{l}\text { 4. Support from local governments and } \\
\text { other agencies }\end{array}$ & 0,15 & 3 & 0,45 \\
Total & & & 0,45 \\
$\begin{array}{l}\text { Threat } \\
\text { 1. The emergence of new competitors } \\
\text { establishing similar Islamic boarding } \\
\text { schools which are superior in several ways. }\end{array}$ & 0,20 & 4 & 0,8 \\
$\begin{array}{l}\text { 2. Reduced interest from donors because } \\
\text { the programs implemented did not go } \\
\text { according to plan } \\
\text { Total } \\
\text { Total number }\end{array}$ & 0,15 & 3 & 0,45 \\
\hline
\end{tabular}

\section{Matriks Evaluasi Faktor Eksternal (IFE)}

\begin{tabular}{|l|l|l|l|}
\hline Internal Strategy Factor & Weight & Rating & Score \\
\hline
\end{tabular}




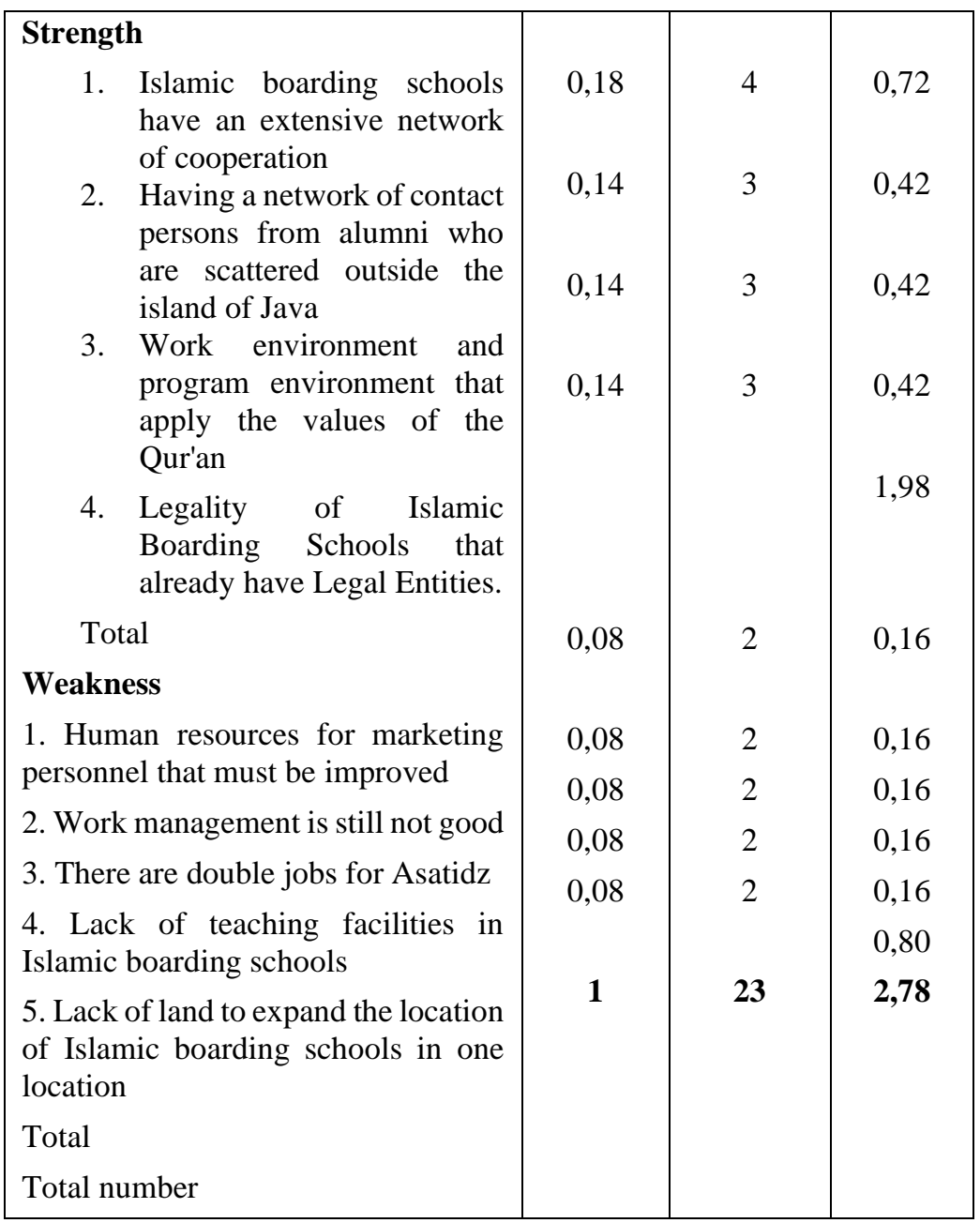

\section{SWOT Analysis Quadrant}

The SWOT analysis quadrant uses the results of the IFE matrix analysis and the EFE Baitul Qur'an Islamic Boarding School matrix. The results of the IFE matrix analysis obtained a total strength score of 1.98 and a weakness of 0.80 . While the EFE matrix obtained a total opportunity score of 2.15 and a threat of 1.25 .

The $\mathrm{X}$-axis is obtained from the reduction in the total strength score minus the total weakness score, namely 1.18 . And the $\mathrm{Y}$-axis is obtained from the reduction in the total opportunity score minus the total threat score which is 0.9 . 
97 |Gina Rohadatul Aisyi, Lutfi Zulkarnain : SW0T Analysis in an Education Institution (Baitul Qur'an Islamic Boarding School, Depok)

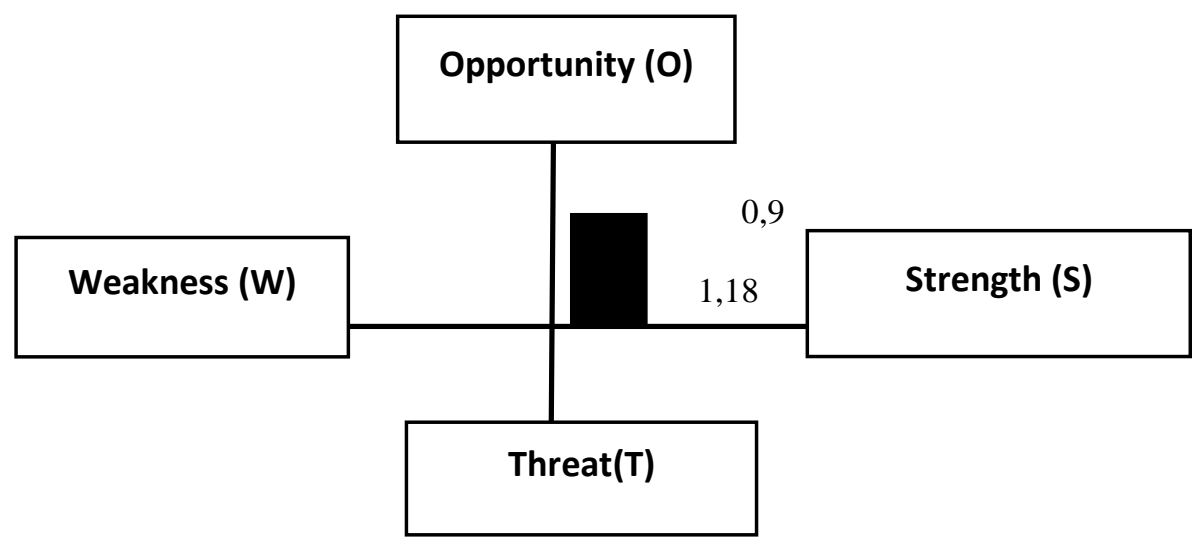

From the SWOT analysis quadrant above, it can be concluded that the company is in Quadrant I (positive, positive), illustrating that the company experiences strength in various ways (internally), so that profitable opportunities are easily achieved. This quadrant is very profitable for the company. For this reason, the strategy must be established to support aggressive growth and development policies.

The alternative strategy that can be applied by the company is the SO strategy (Stregth-Opportunities), namely by taking advantage of the opportunities the company has by optimizing the existing strengths.

\section{SWOT MATRIX ANALYSIS}

\begin{tabular}{|c|c|c|}
\hline Internal & Strengths & Weaknesses \\
\hline & $\begin{array}{l}\text { 1. Islamic boarding schools } \\
\text { have an extensive network } \\
\text { of cooperation } \\
\text { 2. Having a network of } \\
\text { contact persons from alumni } \\
\text { who are scattered outside } \\
\text { the island of Java. } \\
\text { 3. Work environment and } \\
\text { program environment that } \\
\text { apply the values of the } \\
\text { Qur'an } \\
\text { 4. Legality of Islamic } \\
\text { Boarding Schools that } \\
\text { already have Legal Entities. }\end{array}$ & $\begin{array}{l}\text { 1. } \begin{array}{l}\text { Human } \\
\text { resources for } \\
\text { marketing } \\
\text { personnel that } \\
\text { must } \\
\text { improved be }\end{array} \\
\text { 2. Work } \\
\text { management is } \\
\text { still not good } \\
\text { 3. The teachers or } \\
\text { Asatidz have } \\
\text { double jobs for } \\
\text { 4. Lack of teaching } \\
\text { facilities in } \\
\text { Islamic boarding } \\
\text { schools }\end{array}$ \\
\hline
\end{tabular}




\begin{tabular}{|c|c|c|}
\hline & & $\begin{array}{l}\text { 5. Lack of land to } \\
\text { expand the } \\
\text { location of } \\
\text { Islamic boarding } \\
\text { schools in one } \\
\text { location }\end{array}$ \\
\hline External & Strategy S-O & Strategy W-O \\
\hline $\begin{array}{l}\text { Opportunities } \\
\text { 1.Marketing } \\
\text { technology } \\
\text { increasingly } \\
\text { developing, } \\
\text { providing } \\
\text { opportunities for } \\
\text { wider market } \\
\text { development } \\
\text { 2. Good relationship } \\
\text { with donors } \\
\text { 3. Many Islamic } \\
\text { boarding schools are } \\
\text { the same in the } \\
\text { Tahfidz program so } \\
\text { that they can work } \\
\text { together well } \\
\text { 4. There is support } \\
\text { from governments and } \\
\text { other agencies }\end{array}$ & $\begin{array}{l}\text { 1. Optimizing the use of } \\
\text { digital marketing and other } \\
\text { marketing technologies to } \\
\text { support the broad } \\
\text { development of Islamic } \\
\text { boarding schools. (S1-O1) } \\
\text { 2. Develop the quality of } \\
\text { cooperation and use of } \\
\text { relationships with donors } \\
\text { and alumni. (S1, S2-O2) } \\
\text { 3. Evaluating the Islamic } \\
\text { boarding school's tahfidz } \\
\text { method with other pesantren } \\
\text { so that they can jointly build } \\
\text { a better and superior } \\
\text { Tahfidz Islamic boarding } \\
\text { school. (S1, S3-O3) } \\
\text { 4. Compiling several plans } \\
\text { that will be developed in } \\
\text { government coordination. } \\
\text { (S4-O4) }\end{array}$ & $\begin{array}{l}\text { 1. Utilizing } \\
\text { technology and } \\
\text { developing } \\
\text { marketing } \\
\text { promotions } \\
\text { through social } \\
\text { media and other } \\
\text { effective } \\
\text { promotional } \\
\text { media. (W1-O1) } \\
\text { Human resource } \\
\text { management } \\
\text { with a planned } \\
\text { evaluation } \\
\text { pattern, in } \\
\text { collaboration } \\
\text { with other } \\
\text { Tahfidz Islamic } \\
\text { Boarding School } \\
\text { programs. (W2, } \\
\text { W3-O3) } \\
\text { Synergize with } \\
\text { donors to expand } \\
\text { land and } \\
\text { facilities. (W4, } \\
\text { W5-O2) }\end{array}$ \\
\hline THREAT & Strategy S-T & Strategy W-T \\
\hline $\begin{array}{l}\text { 1. The emergence of } \\
\text { new competitors } \\
\text { who set up similar } \\
\text { Islamic boarding } \\
\text { schools which are } \\
\text { superior in several } \\
\text { ways } \\
\text { 2. Reduced interest } \\
\text { from donors because } \\
\text { the programs } \\
\text { implemented did not } \\
\text { go according to plan. }\end{array}$ & $\begin{array}{l}\text { 1. Make new innovations to } \\
\text { develop programs by } \\
\text { maintaining the values of } \\
\text { the Koran. (S3-T1) } \\
\text { 2. Fostering a sense of trust } \\
\text { and loyalty from alumni } \\
\text { and donors to the Pondok } \\
\text { Pesantren program. ((S1, } \\
\text { S2-T2) }\end{array}$ & $\begin{array}{l}\text { 1. Fixing the } \\
\text { company's } \\
\text { internal } \\
\text { weaknesses, } \\
\text { planning targets } \\
\text { and strategic } \\
\text { programs to be } \\
\text { used by Islamic } \\
\text { boarding schools } \\
\text { appropriately. } \\
\text { (W1,W2-O1) }\end{array}$ \\
\hline
\end{tabular}


99 | Gina Rohadatul Aisyi, Lutfi Zulkarnain : SW0T Analysis in an Education Institution (Baitul Qur'an Islamic Boarding School, Depok)

\section{CONCLUSIONS}

The results of the SWOT analysis quadrant concluded that EFE (External Factor Evaluation), IFE (Internal Factor Evalution), and SWOT concluded that Baitul Qur'an Islamic Boarding School was in Quadrant I (positive, positive) with an alternative SO (Stregth-Opportunities) strategy, namely Optimizing the use of digital marketing and other marketing technologies in supporting the development of Islamic boarding schools in a broad sense, developing the quality of cooperation and utilizing relationships with donors and alumni, evaluating the Islamic boarding school's tahfidz method with other pesantren so that they can jointly build a better and superior Tahfidz Islamic boarding school, and Develop several plans to be developed in government coordination.

Then, based on the QSPM matrix in the strategy decision stage, the strategic priority used with the highest total attractiveness value is Optimizing the use of digital marketing and other marketing technologies to support the development of Islamic boarding schools in a wide area $(6,87)$, Developing the quality of cooperation and utilization of relationships with the donors and alumni $(6,86)$, and compile several plans that will be developed in government coordination (6.65).

Based on the conclusion of the QSPM above, the suggestions for this study are prioritized by strategic suggestions for the company, namely:

1. Optimizing the use of digital marketing and other marketing technologies to support the broad development of Islamic boarding schools. Because by utilizing communication and information media, it can maximize partners' needs for information and attractiveness, for example by activating the use of social media that they already have in providing. Also optimization in terms of Technology means that a special teaching system is needed in this regard. So that it can be focused effectively. Maybe with training, working with those who have experts in this field.

2. Developing the quality of cooperation and use of relationships with donors and alumni. Moreover, Baitul Qur'an Islamic boarding school places donors and alumni as part of the heart of the pesantren. Therefore, the strength of the cooperative relationship must always run well. Things that need to be considered are transparency, trustworthiness, maintaining commitment, and building effective communication such as sending regular online reports.

3. Compiling several plans that will be developed in government coordination. Good planning certainly determines how the future results. Therefore, to find out how to make plans run well and in accordance with the government's direction, it is necessary to have careful planning, the importance of mutual perception, mutual openness, mutual respect, and informal communication that need to be built.

4. Further research can carry out research with different theme methods in order to provide benefits to Islamic boarding schools widely and to become better. 
5. Islamic Boarding Schools can implement financial statement management systems in accordance with the guidelines for the preparation of Islamic boarding school accounting guidelines, namely the Financial Accounting Standards for Entities Without Public Accountability (SAK ETAP) in order to facilitate each financial reporting.

\section{BIBLIOGRAPHY}

Alma, B. (2007). Manajemen Pemasaran dan Pemasaran Jasa. Edisi Revisi. Bandung: Alfabeta.

Arham, M. (2010). Islamic perspectives on marketing. Journal of Islamic Marketing, 149-164.

Buchari, A. (n.d.). Pemasaran Stratejik Jasa Pendidikan.

Buchari, A., \& Hurriyati, R. (2009). Manajemen Corporate \& Strategi Pemasaran Jasa Pendidikan. Bandung: Alfabeta.

David, F. (2008). Manajemen Strategis Konsep. Jakarta: Salemba Empat.

David, F. (2008). Manajemen Strategis Konsep. Jakarta: Salemba Empat.

David, F. (2011). Strategic Management: Concepts and Cases. (13rd Ed). Florence, South Carolina: Prentice Hall.

David, F. (2012). Manajemen Strategi. Jakarta: Salemba Empat.

Dhofier, Z. (1994). Tradisi Pesantren Studi Tentang Pandangan Hidup. 44-45.

Dr. H. M. Suyudi, M. A. (2005). Pendidikan dalam perspektif Al-Qur'an. 55.

Dr. Mastuhu, M. M. (1994). Dinamika sistem pendidikan pesantren. Rina J.R. Gitosudarmo. (2001). Strategi Analisis SWOT.

Griffin, R. (2010). Binsis. Jakarta : PT. indeks .

Hasan, A. (2010). Marketing Bank Syariah. Bogor: Ghalia Indonesia.

Jogiyanto. (2005). Sistem Informasi Strategik untuk Keunggulan Kompetitif.

Kartajaya, H. (2010). Perjalanan Pemikiran Konsep Pemasaran Hermawan Kartajaya. Surabaya: Erlangga.

Kasmir, SE, MM. (2008). Pemasaran Bank. Jakarta.

Keller, P. K. (1997). Managemen Pemasaran. Jakarata.

Kertajaya, H., \& Syakir, M. (2006). Syariah Marketing. Bandung: Mizan Pustaka.

Kotler. (n.d.). Marketing Managemen. In U. S. River. Prentice Hall.

Kotler, P. (1999). Manajemen Pemasaran. Dalam Analisis, Perencanaan, Implementasi dan Pengendalian (Vol. 2, hal. 14). Jakarta: Lembaga Penerbit FE-UI.

Kotler, P., \& Lane Keller, K. (2008). Manajemen Pemasaran Edisi 13 Jilid 1. Jakarta: Erlangga.

Lovelock, C., \& Laurent K Wright. (2007). Manajemen Pemasaran Jasa. Jakarta: PT. Indeks.

Lupiyadi, R. (2006). Manajemen Pemasaran Jasa. Jakarta: Salemba Empat.

Mahmud, M. (2012). Manajemen Mutu Perguruan Tinggi. Jakarta: PT Raja Grafindo Persada.

Masyhudi, M. (2005). Manajemen Pondok Pesantren. Jakarta: Diva Pustaka. 
101 | Gina Rohadatul Aisyi, Lutfi Zulkarnain : SW0T Analysis in an Education Institution (Baitul Qur’an Islamic Boarding School, Depok)

Minarti, S. (2012). Manajemen Sekolah. Yogyakarta: Ar-Ruuz Media.

Munif, M. H. (i992). Pondok Pesantren dalam Kancah Kemerdekaan dan Pembangunan Pedesaan. (S. Wijaya, Ed.)

Nasution, M. (2004). Manajemen Jasa Terpadu. Bogor: Ghalia Indonesia.

Ningrum, N. K. (2016). Strategi Keunggulan Bersaing Pada Lembaga Pendidikan dan Pelatihan Magistra Utama Jember. Jember: Universitas Jember.

Noor, J. (2011). Metodologi Penelitian: Skripsi, Tesis, Desertasi, dan Karya Tulis Ilmiah. Jakarta: Kencana Prenadamedia Group.

Philip Kotler, d. K. (2009). Managemen Pemasaran. Jakarta.

Rangkuti, F. (2003). Analisis SWOT Teknik Membedah Kasus Bisnis Reorientasi Konsep Perencanaan Strategis Untuk Menghadapi Abad 21. Jakarta: Gramedia Pustaka Utama.

Rangkuti, F. (2004). Analisis SWOT Teknik Membedah Kasus Bisnis, 18.

Rangkuti, F. (2006). Anlisis SWOT Teknik Membedah Kasus Bisnis. Jakarta: Gramedia Pustaka Umum.

Rangkuti, F. (2006). Pemasaran Jasa. Cetakan Kelima. Jakarta: PT. Gramedia Pustaka.

Riduwan. (2005). Belajar Mudah Penelitian untuk Guru-karyawan dan Penelitian Pemula. Bandung: Alfabeta.

Robbin, S. d. (2007). Managemen. Jakarta.

Robbins , S. (2009). Manajemen. Jakarta: PT Indeks.

Robert W.Bradford, P. D. (2007). Simplified Strategic Planning. A nonsense Guide for Busy People Who Want Result Fast, 142.

Susanto SE, H., \& Umam S.IP, M.Ag, K. (2013). Manajemen Pemasaran Syariah. Bandung.

Sutisno, O. (1985). Administrasi Pendidikan. Bandung.

Suwandiyanto. (2010). Managemen Strategi. Jakarta.

Tjiptono, F. (2008). Service Manajement Mewujudkan Layanan Prima. In Andy. Yogyakarta.

Tresnati, R., \& Maharani, N. (2014). Kajian tentang Strategi Pemasaran Syariah dalam Penguatan Daya Saing UKM menghadapi AEC 2015 di Indonesia. proceedings $S N E B$, (p. 7). Bandung.

Umar, H. (2001). Strategic Management in Action: Konsep, Teori dan Teknik Menganalisis Manajemen Strategis. Jakarta: PT. Gramedia Pustaka Utama.

Usman, A. H. (2015). Managemen Strategi Syariah. Teori, Konsep dan Aplikasi, 20.

Wiryosukarto, A. H. (1996). dari Gontor Merintis Pesantren Modern.

Zamakhsyari. (2011). Tradisi Pesantren. Studi Pandangan Hidup Kiyai dan Visinya Mengenai Masa Depan Indonesia. 